\title{
Human Library and Its Application in college students' Ideological and Political Education Innovation Mode
}

\author{
Liu Tian \\ Sichuan University of Arts and Science
}

\begin{abstract}
The goal of Human Library lies in disapproval of violence, encouragement of communication and elimination of prejudice. The paper tries to study the application of Human Library to the university students'ideological and political education based on the theoretical framework of the connotations and development of Human Library, with the objective of exploring new paths for the university students'ideological and political education and providing some enlightenment.
\end{abstract}

Keywords-Human Library; Living books; University students'ideological and political education

\section{HUMAN LIBRARY PROFILE}

Human Library initially between one kind of person and person through dialogue to reduce the bias, encourage the understanding of educational activities. In the activity, provide a relatively flexible and loose dialogue and exchange place Human Library for the reader, the real books of different types of readers; understand each other through to communicate with the aim of eliminating prejudice. In recent years, Human Library has developed to the professional knowledge, subject and trend.

\section{A. Human Library origin}

In twentieth Century 90 in the early 1990s, Copenhagen Denmark Ronnie burger in five young launched

"stop violence (Stop the Violence)" non-governmental you th organizations, trying toper education way to persuade young people against violence. They think that everyone has a tendency to violence; if there is a chance with his enemy face to face communication, have the opportunity to resolve the misunderstanding, the elimination of violence. In 2000 July, at the Roskilde Music Festival, "stop the violence" organization has lent 75 books "real books (Human Book, also called Living Book)", and achieved very good results, obtained the positive evaluation of the society. Human Library (also called Living Library) the resulting.

\section{B. Human Library practice at home and abroad}

Human Library since 2000 in Denmark has appeared, soon spread to other countries, causing the local library circles, and implanted in the service of the library. Such as the Copenhagen Public Library Central Library of Denmark in 2005 organized the first real library activities. In Sweden in 2006, the library of Malmo city hosted the reality of library activities, this is the earliest of the reality of Library activities. In 2008 October, real library first landed in America, the venue for the city of California USA Panicked Santa Monica public library, then had 14 the real books can be lent, content mainly includes the nudists, Buddhists, vegetarian, well-known publishing house, Oaxaca Americans, homeless women and so on [1].

Most early Human Library concept to domestic is a Chinese American library science experts had bud Mrs.. In 2008 L2 month 16 days, had 2008 Digital Frontier Problems in bud Professor Library hosted by the Shanghai Jiao Tong University library "senior seminar" on the initiative tallow participants to participate actively in the activities of domestic first Living Library. Finally, by 15 LIS experts as a "real books" participants "borrowing". Since then, the university library more and more domestic began to try the Human Library activity.

\section{ACADEMIC LIBRARIES COMBINED STUDENT ORGANIZATIONS TO CARRY OUT HUMAN LIBRARY ADVANTAGE}

College student association is the campus informal groups, are the students in learning, life according to the interests and hobbies, voluntary, according to the articles of association of independent activities, students organization. According to incomplete statistics, the national average in each college has 40 student clubs, 50, more than $60 \%$ students belonging to one or several societies, and more than $90 \%$ of the students took part in some activities held by the club. This shows that in recent years, with the continuous deepening of reform of higher education system and the comprehensive promotion of quality education, the number and the number of students associations are flourishing in China [5].

A. Student associations more easy to explore the quality of Human Books

Human Library Human Books is a decisive factor, directly related to the success or failure of the activity, so as much as possible to explore various types of high quality Human Books became the first should be taken into consideration. University library environment is relatively closed, can come into contact with some of the more specialist schools of scholars, although it could lead to a Human Library to the subject, the knowledge of the 
direction of development, but easy to fall into the didactic mode, can not cause the student reader's interest, but also in the organization of experience is not mature conditions can easily evolve into the traditional lecture instead, the essence of the meaning of Human Library. All the members of student organizations are from the students, they become more familiar with and understand the various "around your expert" and special experience of the people. These people may be experts in study, may be a specialist (not necessarily academic fields), and also may be just one in the process of growing different story man. In order to carry out the activities of the early

Paragraph, such Human Books sure to attract more students to the reader's eye. And because Human Books is as a volunteer, by the student society's classmate invitation is also easier to persuade them to Human Library as Human Books. In addition to the school resources, through the college student association association relationship can also go to other colleges and universities of high quality Human Books, so as to provide the dynamics of Library activity of Human in University library.

\section{B. Student associations active thinking, propaganda way more plentiful}

Already in today's society, information dissemination way become diverse, and college students are undoubtedly the most sensitive group new things. Their active thinking, quick response to all kinds of new media, the community more Canglongwohu, design, planning, art, cal ligraphy,photography and other professional talents are numerous, provide rich human resources guarantee for the inevitable Human Library propaganda work. Production, from the early posters publicity slogans, to the end of the news release, student associations have incomparable advantages over the single community library. They can be the first time perception on the network popular language, with novel copy to reveal and "read some characteristics of each of the Human Book", arousing the readers interest; can also use micro blogs and other new mediator quickly will Human Library the

concept spread to the deep heart, and after the event quickly through all kinds of video website will the activity process release out to harvest more attention activities; also can be the most convenient understanding current hot readers concern, targeted to find "the book for readers". The university library only use various means to Human _ Library is rooted in the students, to make with endless vitality of the transformation of the way of reading, and not just a flash in the pan.

\section{Student organizations can assist libraries in Colleges and universities do a good job in Human Library's organizational work}

Human Library wants to continue to carry on, in addition to a rich variety of Human Books, the activities of the organization work is also very important. This includes pre Human Books acquisition, cataloging, indexing, the whole event planning, publicity, making borrowing rules, for the borrowing formalities, venue layout, service related work process of reading and activities after the end of the information feedback. University Library due to both circulation and reading all services, can not put all personnel are deployed to the Human Library organization work, then the student groups, especially the volunteers played a great role.

The library is responsible for formulating the activity rule and the activities of the program in detail, to grasp the scale of activities and processes in general, specific affairs during the period are by the student societies assist. As for Human Books to recruit, screen, arranged the venue, to provide services for the Human Books and the activities of readers, through the questionnaire, individual interviews to collect feedback information and soon after the event. On the vitality of the university students, this new thing can stimulate their enthusiasm and creativity greatly, can provide a stage for their ability to play, but also can solve the problem of the shortage of University library.

\section{THE MODE OF OPERATION, THE \\ HUMAN LIBRARY MODE IS INTRODUCED INTO THE IDEOLOGICAL AND POLITICAL EDUCATION OF COLlege Students}

Ideological and political education of college students of traditional mostly with counselors is dominant, i.e. in the school management and leadership, management and education of student counselor directly. The Human Library mode is introduced into the college students' Ideological and political education, broaden the channels of Ideological and political education, mechanism and form of innovation of the ideological and political education, let the students have the content of education, more and more targeted teaching object and more autonomous education optional mode, to a certain extent, mobilize the positive factors involved in to the college students' Ideological and political education, the college students' Ideological and political education work is more comprehensive, active, reliable.

The recruitment of 1 "real books" books source. That is, to fully tap the Human

Library in college students' Ideological and political education in the source of books, in addition to make full use of existing school of resources, but also should fully mobilize social resources, the existing resources of campus dominates, outstanding student representative, school, voluntary, have a large stock of information, rich experience and wisdom of the scholars and teachers are the main "source book" reality library, at the same time, the social outstanding representative, such as opinion leaders can be incorporated into the ranks of the book source, recruitment form: introductory, alumni recommend, school selection etc..

Determination of the quality of 2 "real books" book source book source, ensure that the product

Quality. In confirmation of source of quality in the process, should adhere to the principle of orientation, must hold to the correct political orientation. "Real library" mode is the typical individual media, in the interactive space relative to private, between the reader 
and the "source book" can be free to express different political views, which is bound to affect the political tradition, political system or the political democratic process. The face value of pluralistic society, everyone has their own outlook on life and value, this is the concept of society is more and more open results. An advocate of free choice society does not mean there is no non social right and wrong. Face in the social transition period of confusion, the ideological and political education workers should insist on the correct outlook on life and value; be in "real library" mode, and not for good information, public opinion gatekeeper.

The management and protection of 3 "real books", mainly for filing and classification for the recruitment of the book source. Book source classification preliminary ideas for: public share class, new knowledge class, social classes and skills category four categories. Public sharing is to help different charity organizations free planning activities, will build into a public book, allowing more people to read it and understand it; the new knowledge is invited to different age and occupation, have different skills, and in their own positions a little result really came to share knowledge, such as the writer and the director, architect, psychological doctor, and so on; social class is having the same characteristics meet each other real books in the library, reading, looking for love. For example, the birthday the same day, or is the constellation of the same, and the so-called "love" includes like-minded, honey, lovers; skills also regularly launch real computer operation, manual book, workplace etiquette demonstration, Office operating system, the Western cooking, sewing handmade products skills.

4 Human Library after a period of "source book" selection, management, classification and other links, can be applied to college students' Ideological and political education. A good book source selection and classification management based on simple, students can clearly choose their owned to borrow "real books" living books source for special counseling to "borrow" object, and student exchange in their own areas of expertise, to educate students, enrich their own purpose. The process requirements and the smooth implementation of school counselors to make regulations system and a series of effective measures, guarantee the reality source book and students' interests. For example, a single "real books" lending time, lending to

Point and exchange each other rights and obligations clearly etc... Human Library is a kind of education method based on dialogue, unified management in the school, live source book and college counselor's member; undertake the college students' Ideological and political education. Have communication and exchanges between the living books full of counselors, source and students: on the one hand, through various channels to explore and counselors interview various reality source book, pick up the desired real book source; on the other hand, human source book and student exchange with each other, and the students also can feedback AC and real book source to the counselor, counselors according to instant master real books use the schedule and the letter _ interest, overall framework is adjusted real book.

\section{THE INTRODUCTION OF HUMAN LibRARY (7) THE SIGNIFICANCE OF UNIVERSITY LIBRARIES}

The rapid development of the Internet gradually in the replacement of University Library in the information sharing, resource sharing and other aspects of the subject position of library, development space is further extrusion. The library should keep the value of their existence, it must develop thinking, to extend the service function and extend, seek new development path. University Library into Human Library mode, will strengthen communication, in reading function, and promote the harmonious development of tacit knowledge

Has made great progress, and provide the effective mode for the long-term healthy development of University library.

(1) The individual reading pattern can maximally satisfy the demand of readers. Based on the model of reading Human Library library, "book" is played by the personality of the full reality, these "books" from all walks of life, with the knowledge structure of a variety of different, can be said to be "top know astronomy knowledge of geography" "very learned," borrowing readers is the product read of these "books" in particular, the time, the right place, between the reader and the "book" in the exchange of information, mutual borrowing rules to gain knowledge, self personality easy access to knowledge, to solve the problem.

(2) The implicit information resources can maximize the mining and utilization. The library collection, collation, preservation as literature and culture educational institutions provide convenience to readers, not only to develop all kinds of dominant resources, such as books, periodicals, pictures, audio, electronic books, tacit resources should also develop and utilize a large number of higher value, such as the type of intelligence information resources and zero literature etc.. The new reading model Human Library is one of the best books on human, channel

development recessive resources. People can communicat e face-to-face conversation, which rarely appeared in the literature on the verbal information resources and intellectual resources. German Shang Bailout said "life is like a book", everyone is a book worth reading "the book", have rich experience can learn, is worth learning place to mining, is the so-called "three of us are walking together, there must be my teacher behavior".

(3) Adequate communication can maximize harmonious atmosphere. With the continuous development of network information technology, digitalization and informationization has become the main way of daily office and access to information resources, the exchanges between people less communication barriers, obstacles increase, and not harmonious factor is also more and more. 
The Human Library direct communication mode is unique, just make up for defects caused the traditional way of reading, the promotion of human dialogue, enhance mutual understanding, build a harmonious and friendly atmosphere in campus.

\section{REFERENCES}

[1] $\mathrm{Wu}$ Hanhua, the prince week. A new model of developing reader knowledge resources: real library [J]. Library Journal, 2010,29 (9): 21-22.

[2].Http://www.lib.sjtu.edu.cn/view.do ID $=2167$. of Shanghai Jiao Tong University library website?

[3] Study, learn Fan Yanfen.Human Libraray: of Chinese University Library Education andservice innovation of [J]. library 2010, (10): 92

[4] Of the Nanjing Normal University library website.Http://202.119.108.115:81/living/report.html.
[5] Zhou Guojun. Management and [J]. Journal of South China University of Tropical Agricultureon the construction of College Student Association, 2007,13 (3): 75

[6] Yan Chune. Contemporary college students' Ideological and moral status analysis andCountermeasures of $\mathrm{J}$ education. Education and profession, 2007, (33).

[7] Zhao Yifan. The status of Living Library service in academic investigation and analysis of $J_{-}$library science research, 2011 (4)

[8]- Murong Hui. Living Library J. The domestic research on the development of the library world,2011, (4).

[9] Liu Rujian. Our university library Living Library active practice and analysis of J. The Agricultural Library and information science, 2011, (3).

[10] Deng Longkui. The necessity and Countermeasures J Recessive Ideological and political education in University. Journal of Chongqing University of Science and Technology, 2009, (4) 